\title{
Industrial production of concentrated protein from edible mushroom mycelium as food for people
}

\author{
ATANAS TOREV
}

\begin{abstract}
TOREV, A. 1978: Industrial production of concentrated protein from edible mushroom mycelium as food for people. - Karstenia 18 (suppl.).

The use of edible mushroom mycelium, containing a high percentage of protein, all indispensable amino acids, some of the "B" complex vitamins, and a range of physiologically active substances in food has been studied. The mycelium is well accepted by the human organism improving the blood test and increasing its general vitality.

A. Torev, Institute of Agriculture, V.S.I. "Vassil Kolarov" 4000 Plovdiv, Bulgaria.
\end{abstract}

\section{$\underline{\text { Summary }}$}

The traditional protein sources as meat, milk, eggs, fish, and vegetable proteins are not able to solve the world protein problem for the continuous increase in the world population.

The lower organisms could help the solving of this problem when used as sources of microbial protein with high nutritive values and assimilability. For the time being bacteria, yeast, mould, and edible mushroom mycelium are known as sources of microbial protein. In our opinion the best of them seems to be the edible mushroom mycelium for its highest position in systematic, biological, and psychological respect.

our experiments showed that the edible mushroom mycelium contains a high percentage of protein (54$58 \%$ ), all indispensable amino acids, some of the "B" complex vitamins, and a range of physiologically active substances. The protein assimilability is rather high ( $83 \%$ compared to $85 \%$ for first rate veal). When using the edible mushroom mycelium as food for people no disturbances have been observed. On the contrary, it is well accepted by the human organism improving the blood test and increasing its general vitality.

The strains of edible mushroom mycelium isolated by us are adjusted technologically for industrial production. At present a plant is being projected in Bulgaria for the production of edible mushroom mycelium with a year capacity of 10000 tons pressed fungal mycelium.

The edible mushroom mycelium could be put (10$20 \%$ as pressed mycelium) in various sausages, mince meat, meat and vegetable tins, processed and smoked cheese, in different kinds of soups, paste, bread products, etc.

The taste of foodstuffs containing fungal mycelium remains unchanged and with some products as soups and pastes a fine fragrance of mushroom is felt. The prime cost of 1 ton pressed mycelium is three times lower than that of 1 ton veal with the same nutritive and biological values. 